\title{
Human Formation of Young People and Adults in Brazil: Proposal for and Evaluation of a Curriculum Component
}

\author{
Eugenia de P. B. Cordeiro ${ }^{1}$, José Policarpo Junior ${ }^{2,3}$, Ana Paula F. da S. Mota ${ }^{2} \&$ André L. Wanderley $^{2}$ \\ ${ }^{1}$ Instituto Federal de Educação e Tecnologia de Pernambuco, Brazil \\ ${ }^{2}$ Universidade Federal de Pernambuco, Brazil \\ ${ }^{3}$ Instituto de Formação Humana, Pernambuco, Brazil \\ Correspondence: José Policarpo Junior, Instituto de Formação Humana, Rua Silveira Lobo, 32 CP. 146, CEP. \\ 52061-030. Recife-PE, Brazil. Tel: 55-81-3441-2343. E-mail: jpj@formacaohumana.org
}

Received: April 10, 2014 Accepted: May 11, 2014 Online Published: June 17, 2014

doi:10.5539/ies.v7n7p29 URL: http://dx.doi.org/10.5539/ies.v7n7p29

\begin{abstract}
The article is based on the idea of human formation in its broadest sense, which includes the formation of the senses, corporeality, habits and practices, emotional life, the cultivation of relationships and of reflection on the existential meaning of the singular human life. It is assumed that the postulate is accepted that education is a specific and intentional process of human formation, with the same wide-ranging formative objectives of such formation. The article situates this understanding of education in the Brazilian educational field and presents a curriculum component designed to promote the human formation of young people and adults in technological training establishments in Brazil, over 18 weekly meetings of three hours each. This curriculum component was implemented and evaluated with 206 students from different technological courses by means of pre-and post-testing with a questionnaire, using a Likert technique, drawn up especially for this research study. It is designed to gauge (a) the understanding of relationships and emotions, (b) the understanding and cultivation of the virtues, and (c) the predisposition to take responsible decisions and actions. The results showed a statistically significant difference in the three subscales between pre and post-testing, with the higher scores being achieved in the latter.
\end{abstract}

Keywords: human formation, emotional education, young people, adults, individuation

\section{Introduction}

This article is one of the partial results of research conducted between 2008 and 2012, which set out to develop, implement and evaluate a proposed curriculum component to promote the human formation of young people enrolled in higher technological courses in Brazil. Such courses are classified as being Higher Education ones as they are mounted for students who have completed high school, but its main goal is to form professionals to meet market demands in less time (two and a half years to three years) than the content provided in a traditional university course that lasts for at least four years.

We intend to develop this curriculum component to ally to professional formation a personal formation of the students which might cover gaps that we have noted in our contact with them over several years. Among these gaps, we have noted that the technical and vocational content did not prepare them for relationship challenges of an intrapersonal and interpersonal order bearing in mind that the skills that involve cooperative teamwork have been recognized as key to success at work and in life. Among such skills we draw special attention to: emotional control to handle relationship tensions and stress; self-knowledge in order to monitor impulsive actions and anxieties as well as to cultivate an inner life based on values and also to hone listening so as to steer communication towards healthy and constructive ends.

Given such findings, we considered it would be important to provide students with a type of personal formation that would help them: to become familiar with the dynamics of their inner life, thereby becoming able to link it to their relationships, their behaviors and practices; to strengthen themselves individually vis-à-vis the social demands and manipulative forms of advertising; in short, to be able to establish for and in themselves a congruence between what they consider valuable, what they aim at, what they think, what they feel, what they practice and how they relate with their fellows. 
The curriculum component mentioned, which will be described in detail in Section 3 of this article, was designed to be taught as the subject content of "Interpersonal Relations" which previously appeared on the curriculum of vocational technology courses of a federal institute in which one of these authors has been working for several years. Therefore, the inclusion of this component did not imply a formal change in the curriculum of the courses to which we are referring but only a change of content of that discipline.

When we were drawing up this curriculum component, we were aware that such formation objectives are not learned at random but should be part of an intentional effort such that humans take ownership of them, as attested to in international documents that state the need for education to be structured in order to promote learning to know, to do, to be and to live together (Delors et al., 2003; United Nations Educational, Scientific and Cultural Organization [UNESCO], 1972; UNESCO-Asia Pacific Network for International Education and Values Education [APNIEVE], 1998, 2002, 2005). Therefore we did not see any incompatibility between this desirable personal formation and professional formation on which the structure of the technology course was targeted and into which we intended to insert the component referred to. We understand that the set of all these formative aspects comprises what we identify as human formation, an idea that we intend to present in more detail, albeit in succinct form, in Section 2.

In considering the challenge to design and deliver such a curriculum component, we would also need to assess its possible results. With this understanding, we carried out such an assessment by quantitative and qualitative means, though, in the scope of this article, we only have the space to present the quantitative results obtained.

Given the aspects considered, this article is structured into the following Sections besides this introduction: (1) presentation of the idea of human formation that underpinned the design of the curriculum component and all the research, (2) characteristics of the intervention and curriculum component designed, (3) method, (4) results, (5) discussion and concluding remarks.

\section{On the Idea of Human Formation and Its Relationship with Education}

The nature and purpose of this research are characterized by this topic still being unusual within the academic field in Brazil and, more especially, in the area of education. In Brazil, the educational field has not yet been structured so as to become permeable to the study and implementation of ideas regarding the formation of human beings in a broad understanding of this term which is why the very expression "human formation" is not yet sufficiently understood or is accepted in a distorted or limited way in the field of educational studies in this country. The few studies that deal with the topic in question (Rodrigues, 2001; Policarpo Jr., 2011; Policarpo Jr. \& Rodrigues, 2010; Röhr, 2013) generally do so only from a theoretical or philosophical point of view, and have not yet managed to transpose such understanding to specific practices or models of intervention that can be scientifically evaluated. As stated earlier, the research that gave rise to this article set out to draw up, implement and evaluate a curriculum component structured according to the concept of human formation, and therefore was characterized not only as being bound to theoretical discussion on the topic but also and equally targeted analyzing this concept experimentally. At the same time, in order to make the foundation and the research procedures clearer, we present below a theoretical overview of how we conceive human formation.

The idea of human formation rests on an approximate understanding of what a human being is. We say "an approximate understanding" because we recognize that no theory or thinker may lay claim to reaching an exhaustive knowledge of human beings, no matter how great their scientific and philosophical contributions towards this is or has been. A certain formation, the legitimacy of which is based on the degree to which it is adapted to the nature of such a being, is related to this understanding of the human being. Thus, for example, since we know that the human being possesses a nature that can only be developed in society, together with other human beings, it becomes clear that this being needs to appropriate to itself the greatest possible diversity of acts that shape the historical, social and cultural world in which people, their fellows, inhabit. For this reason, a fact that is understandable is that of educational systems being structured with a sense of providing the acquisition, by particular individuals, of diverse intellectual and attitudinal skills and disciplines that characterize countless achievements of the culture; there are no lack of arguments to justify the schooling tradition that was established around this objective in various countries and modern societies.

However, cultural achievements themselves do not only require this kind of intellectual training in addition to which a human being is not only a social and cultural being, but is also a being-species, i.e., a being of the human species, and also a personal and unique being. To this broadened understanding of the human being, a formation should also correspond which may have as its scope to foster a human form developed from all the aspects that constitute its being. This means that the constitution of the human being is expressed as a parameter of that formation that should, by nature, correspond to it. Authors such as Policarpo Jr. and Rodrigues (2010) 
deem such an understanding a normative aspect of human formation. By means of the concept of a normative dimension, it is possible to understand that the very constitution of the human tells us not only what this is, but equally what it can and should come to be. With that understanding, we can comprehend, for example, that our bodily dimension has certain intrinsic characteristics which require certain minimum and maximum calorific parameters from food, as well as a certain variety and amount of proteins, vitamins, etc. which, when they are not observed may well lead to harming to our health. Similarly, all human beings have an emotional-sentimental dimension that they need to know, monitor and guide in the sense that this aspect may be able to express itself in the most harmonious way possible with the other dimensions of our being. These aspects require cultivation, an appropriate formation that cannot happen at random, but rather in a conscious and guided manner. According to what has just been set out, therefore, this normative reasoning applies to all the constituent aspects of the human, including: (a) its organic-corporal structure; (b) its external and internal sensibility which is expressed by means of instincts, emotions and feelings; (c) its mental constitution; (d) its opening constitution not determined to others, to the contexts and to the sources of meaning for its social, cultural and personal-existential life.

As to the condition of being a being-species, a historical, social and cultural being, and a personal being, on considering such complexity of the human we are led to recognize that its constitution demands a formation that integrates all these aspects such that it may fit them and may make sense to every single human being. This understanding, however, points to the idea of integral formation of the human (Röhr, 2012, 2013) which cannot be reduced to the cognitive aspect but seeks to integrate organic-corporal formation (the cultivation of vitality, health and strength of the organism and its appropriate expression, for example), the formation of emotions and feelings, the development of self-awareness, the ability to be open to the other and to reflect on the values that in principle should govern relations between humans.

Having admitted the legitimacy of the integral formation of the human being, what equally comes into relief is an understanding of the normative need for unification or congruence of its various aspects or expressions such as thinking, feeling, action (Röhr 2012; Policarpo Jr., 2011, 2012; Ferreira, 2012). Therefore, integration does not occur anyway, but in order to respect a condition in which the human being expresses him/herself and lives life fully and coherently. This is no other than the meaning of the word "individual", on pointing to the desirable state of the particular being who overcomes his/her internal and external divisions by unifying his/her various dimensions of being. It is, therefore, the idea of individuation (Jung, 2007; Preece, 2006; Policarpo Jr., 2012) which alludes to the sense of the particular human being unifying him/herself, overcoming the divisions between his/her thinking, emotions and feelings, body and actions, while at the same time developing collective skills inspired by values that put him/her on the path to his/her own wholeness. No individuation can occur when the particular individual allows him/herself being led unconsciously by his/her instincts and emotions, since these, by themselves, do not have the necessary enlightenment to foster the integration to which every single being one is called. The individuation that is expressed by the coherence of individuals, therefore, requires the guidance of thinking, conscious feeling and acting with consequence and responsibility. It is in this way, therefore, that the process of individuation requires social and emotional education (Goleman, 2003; Elias et al., 1997; Zins, Weissberg, Wang, \& Walberg, 2004; Kusche \& Greenberg, 1994, 2012; Greenberg \& Policarpo Jr., 2008) guided by values, so that the personal being can progressively become familiar with the psychic energy that inhabits it, thus becoming aware of it through self-observation and self-control. Thus, knowing how to denominate and recognize what one feels, experiencing all the feelings and emotions, but not getting carried away by them is the necessary precondition such that the unique human being can exercise the ability to monitor and guide what he feels, without repressing it, but equally without falling under its domain, also.

Integrating oneself, individuating oneself, being able to monitor one's emotions and acting consciously are skills or abilities that become more developed to the extent that the particular subject starts to cultivate a healthy and aware mind (Kabat-Zinn, 2005; Kornfield, 2002; Dalai Lama XIV, 2012) or who exercises self-awareness. Thinking about one's own thinking, about one's feelings and emotions, about one's actions, about one's wishes and about one's preferences and values is fundamental for someone to steer his/her own life with propriety and is therefore equally a normative aspect of human formation to which individual beings should submit themselves. It is equally by means of self-awareness and the ability to think about all the aspects related to their life that human beings also achieve the ability to reflect on and guide themselves when cultivating human values (López-Quintás, 2004; UNESCO, 1972, UNESCO-APNIEVE, 1998, 2002, 2005; Gardner, 1999; Biaggio, 2002) thus paving the way for a meaningful and fulfilling life, because when a human being rationally understands what underpins values, the existential commitment to the flow of living ethically becomes more natural. In this condition, the individual being begins, naturally, by him/herself, without outside coercion, to guide him/herself in the sense of avoiding harm to third parties and to behave in a valuable way for him/herself and others. None of 
this, however, can arise without the human being heading in the direction of his/her integration, individuation, emotional development and monitoring, and exercising self-awareness. On advancing in this formative process, the individual being will more easily recognize the need and validity of cultivating principles such as the equality between human beings, the pursuit of truth which serves as a guide to oneself, and giving value to attitudes and practices that are useful to oneself and others (Policarpo Jr. \& Röhr, 2012).

Only when a human being commits him/herself and starts out on the long personal road to set the bearings for his/her life and steer it according to these normative principles, even if he/she can never manage to bring them fully about, he/she will nevertheless be in a state to recognize freely and autonomously the need and the mode of open themselves to the other and to those like themselves. Of course we all start a process of being open to the other long before we are aware of doing so. Nevertheless, just because many never reach awareness about the need and the richness of the encounter with the other is why so many problems and tragedies happen in relationships. Without one's reaching the minimum ability to guide oneself consciously, in an integrated and individuated way, the individual being will scarcely be able to place him/herself in a state of establishing relations with those like him/her, which necessarily entails becoming impoverished as a human being who is, after all, how humans are, we are incomplete without the presence of the other. For this reason, authors such as Erikson (1994) and López-Quintás (2004) stated, in different ways, that the relations of unity with other human beings need to be cultivated, i.e., they do not spring to life at random, and cultivating them requires the individuals to be able to come out of their own centeredness, which can only be done when they are able to integrate themselves, individuate themselves, monitor and guide their emotional lives minimally and exercise their self-awareness because only someone who may have achieved such capabilities can stop being subjugated by more primitive forces of an instinctive and emotional character which do not have the wisdom in themselves to guide human beings. As López-Quintás (2004) said, to establish relationship of encounter with another human being, the individual needs to cultivate values such as generosity, trust and loyalty, these being qualities that can only arise in someone who acquires and minimally exercises personal congruence. However, should a human being not demonstrate the ability to overcome his/her more self-centered tendencies and therefore is unable to unify him/herself, exercise their self-awareness and cultivate the values that encourage the celebration of the meeting between human beings, nor will he/she be able to reach the richest level of humanization which requires the object relations between people to be overcome (Quintás-López, 2004), and thus condemns him/herself to remain in a self-imposed cloister that leads to failure, isolation and, at its extreme, to depression and despair (Erikson, 1994).

According to the foregoing, and without being able to dwell further on the idea of human formation given the limits of this article, we present the main concepts (Table 1 below) that structure the idea of human formation used in this study, together with their references.

Table 1. Concepts underpinning the idea of human formation and their authors

\begin{tabular}{ll}
\hline \multicolumn{1}{c}{ Concepts } & \multicolumn{1}{c}{ Authors } \\
\hline Integral formation of human beings & Röhr (2012, 2013) \\
$\begin{array}{ll}\text { Normative conception of education and its principles of truth, } \\
\text { equality, utility, introspection, freedom }\end{array}$ & Policarpo Jr. and Rodrigues (2010); \\
Unification or congruence of the different aspects or dimensions & Policarpo Jr. and Rohr (2012) \\
of humans such as thinking, feeling, acting & Ferreira (2012); Policarpo Jr. (2011, 2012); \\
Individuation & Jung (2007); Preece (2006); Policarpo Jr. \\
& (2012) \\
Inter-human encounter & López-Quintás (2004) \\
On emotions and emotional and relational development and & Goleman (2003); Elias et al. (1997); Zins \\
education & et al. (2004); Kusché and Greenberg \\
& (1994, 2012); Greenberg and Policarpo Jr. \\
& (2008) \\
Human values for life and education & López-Quintás (2004); UNESCO (1972); \\
& UNESCO-APNIEVE (1998, 2002, 2005); \\
& Gardner (1999); Biaggio (2002) \\
Cultivation of a healthy and aware mind & Kabat-Zinn (2005); Kornfield (2002); \\
& Dalai Lama XIV (2012) \\
\hline
\end{tabular}


Having presented the main concepts that underlie the understanding of human formation, we recognize it is necessary to clarify that we conceive of education as part of human formation. The latter is broader than the former because it can occur in various contexts and activities, and not always intentionally and guided by someone else, while education is characterized as being an activity and deliberate process of presentation and orientation of formative alternatives to human subjects by other individuals and institutions, in a systematic way. Thus, we understand that all education should be structured in a way that leads to human formation, without, however, ensuring that this objective will necessarily come about given that the intrinsic assumption of this desideratum is the principle that each individual person should reflect for him/herself on, convince and commit him/herself to a formative path, which by definition cannot be ensured beforehand. However, as per the reasoning presented hitherto, the formation of human beings is based on an appropriate normative understanding of one's own being, which does not spring up ready made but needs itself to develop in an appropriate manner. For this reason, although education cannot ensure human formation, when one considers the constitutive freedom of the subject, it is more than likely that the presentation of formative itineraries triggered by the concepts presented will be welcomed by most students because this befits their own being.

Therefore, in the line of the theoretical elucidation of the idea of human formation, we shall, in Section 3, present the structure of the curriculum component which we have designed, making it clear from the start, that we did not have and do not claim that this curricular component will ensure the human formation of young people and adults. Rather, our claim is that students may understand the reasons and significance of cultivating all those elements presented there and feel invited and motivated to do so because the commitment to undertaking or experiencing it is something that exists in dependence on each other. Therefore, the very instrument that we use to measure the results of our intervention is intended solely to verify the degree of acceptance or recognition of the formative principles presented here, but not they have been experienced.

\section{Characteristics of the Intervention and of the draft Curriculum Component}

As already stated, part of the research under discussion consisted of drafting a Curriculum Component for the Human Formation of Youths and Adults (CCFHJA, in Portuguese) enrolled on technology courses in Brazil. We were thus seeking to ally to the technological formation received by such students a formation that might invite them to reflect on their inner lives so that student themselves could attest the theoretical content by exercising self-observation on everyday experiences. Three thematic axes guided the development of this component: understanding interpersonal relationships and knowledge of the emotions; understanding and cultivating virtues, and; predisposition towards responsible actions and decisions. The logic that underpinned the component was based on the idea that the greater the understanding of the individual regarding the signals prompted by the sensory/emotional dimensions and his/her self-control and creativity to transform impulsive acts into conscious actions, this would directly and positively have an impact on their way of acting in the relational framework, thereby facilitating the cultivation of values that might foster collective harmony and well-being.

This curricular component was taught in an exploratory and purposeful way, to 206 students of various technological courses (graphic design, environmental management, radiology, analysis and systems development, tourism and hospitality) of a federal institute, in the Northeast of Brazil.

In subsections $3.1,3.2,3.3$ and 3.4 we present the organization of the curriculum component that was taught over 18 meetings, each lasting $2 \mathrm{hrs} 30 \mathrm{mins}$.

\subsection{Meetings 1 to 7}

\section{General Objectives}

- To analyze the influences surrounding intra and interpersonal relationships regarding everyday experiences

- To promote theoretical studies on the sensory and emotional dimensions and guide students to observe the dynamics of these in the way they feel, think and act

- To direct students to recreate the signals arising from natural impulsive acts with a view to finding skillful means of acting on taking the collective well-being into consideration

\section{Implementation}

- Through debates, discussions, group and pair work, conversation circles and the reading of texts, we endeavored to prompt reflections on the influences of the surroundings on individual decisions, and stressed the manipulative maneuvers that seek to strengthen individualism at the expense of freedom of choice on behalf of the common well-being. 
- In-depth examination of theory on the emotions allied to the experience of self-observation in everyday life. At the end of each meeting, the student took away the task of the exercise of observing when emotions emerge and how these influence their thinking, thus creating a predisposition to immediate actions. The observation process was related to the practice of taking in and pondering on this phenomenon within oneself in order to reduce immediacy and increase the time for making a conscious choice.

- As part of the learning, the students presented seminars on anger, fear and sadness, allying to the theory the study and analysis of a movie scene they had chosen in which the characters constructively or destructively lived out sensory/emotional signals.

\subsection{Meetings 8 to 11}

\section{General Objectives}

- To analyze and reflect on listening, empathy, self-monitoring and feedback

- To guide towards self-observation and self-control of listening, empathy and feedback

- To promote the reflection and practice of conscious feedback of relationships by a process of constructive communication

Implementation

- In-depth examination of theory on listening, empathy, self-monitoring and feedback, allied to group and pair-work dynamics, role plays, analysis of movie scenes, continuity of the exercise of self-observation as an on-going task both inside and outside the classroom.

- These communication elements were worked on as a cycle that feeds itself constructively, initially driven by more attentive and more conscious listening, thereby developing the willingness to listen as an act of love and respect for each other. By means of doing so, we become more able to exercise empathy by observing our barriers as to accepting each other unconditionally, at monitoring our conscious effort to understand the world of the other and paying attention so that we might keep ourselves congruent with ourselves, thus detecting the possible influences of the other in our manner of feeling, thinking and acting. When we exercise with greater awareness each of the steps mentioned above, we can establish a healthy communication and interaction circuit and take responsibility for choosing acts and words that may promote harmony, truth, trust and joyfulness in relationships.

\subsection{Meetings 11 to 14}

General Objectives

- To analyze the damage caused by emotions/feelings that are out of control in a feature film

- To introduce notions of self/ego, thus encouraging individual commitment to developing oneself multidimensionally on behalf of collective well-being.

\section{Implementation}

- We reviewed the theoretical content taught up until that point, analyzing a feature film that depicts the day-to-day lives of an Italian upper middle class family in which the characters relate to each other motivated by thoughtless and uncontrolled emotions. They direct their lives towards objects that are influenced by success as an expression of acquiring goods that the consumer market gives value to (appearance, fun, utilitarian relationships, etc.); they do not solve their internal problems and set out on extramarital relationships as an escape valve and momentary relief from the suffering inherent in disharmonious, individualistic and irresponsible living together: in short, there is an absence of values. We added to the study of the emotions, an in-depth examination of theory on loneliness, frustration and envy, always allied to the self-observation process.

- We introduced the notions of I/ego, from a multidimensional perspective: physical, sensory, emotional, mental and values. We studied and analyzed, by using examples from everyday life, the dynamics inherent in each of these dimensions and that directly impact the way we feel, think and act. We stress the I/ego as an ongoing process and reinforce the importance of our commitment in being more at the time that we understand that we are responsible for recreating the energies/signals emitted by each of these dimensions thus avoiding that we become hostage to them. The dimension of values assumes in this context the normative function in the process of discerning and choosing the attitudes to be taken up. Students are encouraged to see in themselves this dynamic in order to give credence to the theoretical content taught, as a result of their own experience. 


\subsection{Meetings 15 to 18}

\section{General Objectives}

- To analyze and reflect on the path of individuation as a normative target to be covered in the intra and inter-relational exercise

- To evaluate all theoretical content taught in the light of the students' personal experience and the analysis of a feature film

- To reflect on happiness as a meaning to life

Implementation

- As a consequence of the development of a positive individuality by consciously exercising the aforementioned skills, we studied and analyzed the process of individuation as a path to be trodden when seeking the integration/congruence between what we feel, think and act, with a view to finding harmony, peace, joy and happiness from nature and all sentient beings.

- In this block, we conducted theoretical studies and debates on the path of individuation based on Jung (2007) and watched a feature film that contrasts with the previous one in the figure of a teacher in a British boarding school who, by teaching history, seeks to pass on the values cultivated by the Roman Emperors who contributed constructively to the history of mankind. Allied to the theory, the teacher seeks to put into practice the content taught in his day-to-day life with his students. However, one of them, the son of a corrupt politician, reproduces his father's values and behaves provocatively with respect to the teacher, who, as an educator, chooses to develop the character of this student thereby providing opportunities for him to participate actively in academic activities. The response to the behavior of this challenging student reveals the individuated personality of the teacher who besides maintaining self-control in the face of provocation, does not give up investing in edifying this student's values. Despite all efforts, the student frustrates the teacher's expectations both as a student as well as a professionally established adult. Examples of corrupt father prevail. The teacher represents an individuated being who is guided by sound principles and seeks to act coherently, while the student, despite the opportunities given to him, chooses to remain in a corrupt life and without values just as his father does. Therefore, we find the limits of a component that targets the human formation, since we cannot disregard the freedom of human being from joining or not joining a possible path of individuation.

\section{Method}

The formative impact of CCFHJA was analyzed by means of interviews and written statements by students $(\mathrm{N}=$ 206), and also by using a questionnaire based on a Likert type scale constructed specifically for this study. In this article, we present only the results of the analysis using the scale mentioned above, specifically the analysis of the Student's $t$ test for averages of two paired samples between the scores achieved by the students before and after taking the CCFHJA course. The choice of statistical test was based on the Gaussian nature of the indices.

Of the 206 students in the sample, $87(42.2 \%)$ were male and $119(57.8 \%)$ were female. Their average age was 23.6. Also regarding the distribution of the sample by age, the Minimum, $1^{\text {st }}$ Quartile, Median, $3^{\text {rd }}$ Quartile and Maximum values were respectively: $16,19.5,21.5,26$, and 54 , which shows that the subjects were mostly young people.

We developed and used a 5-point scale on attitudes of the Likert type which had 47 items. It was deemed the Scale of Understanding Aspects of Human Formation (ECAFH, in Portuguese). This scale consists of three subscales, namely: Interpersonal relations and knowledge of the emotions (SRICE, in Portuguese); Knowledge and cultivation of virtues (SCCV, in Portuguese); Predisposition to responsible actions and decisions (SPADR, in Portuguese), all of them being based on the principles presented in Sections 2 and 3, in particular with regard to knowledge of the congruence between thinking, feeling and acting; in emotional and relational development; in the inter-human encounter, and; in the cultivation of values for life.

Each subscale consisted of items that affirmed or denied the respective characteristics that should be measured; some items were, therefore, weighted inversely when their content was worded such that it denied the goal that the subscale was to measure.

This scale of 47 items was the end result of a process that began with a pretest scale consisting of 80 items formulated from observations of the students' most recurrent forms of expression regarding their relational experiences. This application was made in the first semester of 2009.1 and served so that 24 items were excluded, taking their legibility and tendentious orientation towards agreement or disagreement into account. The scale was then reduced to 56 items and received the following statistical treatment: 1. Spearman's test of bilateral 
correlation to validate the items 2 . Cronbach's alpha reliability test. After these procedures, we obtained the final version of the scale which then had 47 items.

The criteria adopted to validate items were positive and statistically significant correlations, i.e. those with a p-value less than the level of significance $\alpha$ which was set as being $5 \%$. After having validated the items, we also conducted a statistical analysis of the internal consistency of each subscale or index, taking as a parameter Cronbach's alpha with values greater than or equal to 0.6. All statistical tests were performed using the Statistical Package for the Social Sciences (SPSS, version 17.0).

In Tables 2, 3 and 4, we present the items in each of the subscales, accompanied by the values of the Spearman Rank Order correlation between each item and the mean of each subscale. All the correlation values shown were statistically significant at the significance level of $5 \%$.

Table 2. Items of the subscale on interpersonal relationships and knowledge of the emotions (SRICE) and their correlations (Spearman Rank Order) with the average

\section{Item}

Correlation

1. One of the good things on achieving a good standard of living is being able to choose smart and beautiful people to relate to. (inverse assessment)

2. When I'm sad I don't want anyone to talk to me otherwise I may well react without thinking (inverse assessment)

3. We should hide our emotions from ourselves even if no one notices. (inverse assessment)

4. The emotions make relationships very difficult, without them we could have better balance. (inverse assessme)

5. When my plans do not come off, I feel deeply downcast or very irritated (inverse assessment)

6. When I feel angry, my strength flows and so I stick out my chest at people who are provoking me. (inverse assessment)

7. Although education is necessary for everyone, we have to recognize that some will never become good people for they are born with a bad character. (inverse assessment)

8. Happiness is something that depends on the moment. You either take it or leave it, or else it goes away. (inverse assessment)

9. In relationships, I try to inhibit another's emotions to give myself respect. (inverse assessment)

10. On perceiving my defects, I understand that I am a bad person and do not deserve the good things in life. (inverse assessment)

11. The emotions are meant to be experienced and not understood. (inverse assessment)

12. Most of the time I'm peaceful but no one can "step on my toes" without my becoming a beast. (inverse assessment)

13. The emotions signal how we should act. It is best to follow the feeling of the moment than to be sorry later. (inverse assessment)

14. We must maintain a certain distance from people if we are to be respected and to avoid the difficulties with relationships (inverse assessment)

The Cronbach's alpha calculated for this subscale reached a value of 0.67 , which is considered satisfactory for the humanities (Moroco \& Garcia-Marques, 2006). 
Table 3. Items of the subscale on knowledge and cultivation of the virtues (SCCV) and their correlations (Spearman Rank Order) with the average

Item

Correlation

15. Being loyal is very often the task of talking about the undesirable

16. Without the experience of respect from the family environment, it becomes difficult for anyone to absorb and commit him/herself to respect for oneself and others.

17. Generosity is the ability to give oneself unconditionally. Without wanting anything in return.

18. Not omitting important information to the other is a practice of loyalty

19. The lack of respect of someone to me does not justify my lack of respect for that person.

20. We must do what we are due without expecting any thanks

21. We should only respect those who respect us. (inverse assessment)

22. Our dignity depends on the extent to which we are loyal to our feelings, thoughts and actions

23. There is no way to have a happy relationship without loyalty

24. He who respects himself is neither vindictive nor violent.

25. When someone hurts me immensely, I know that this person is hurting him/herself first and foremost

26. In the world and in life we have many more reasons to cultivate gratitude than to be ungrateful.

27. We must trust but remain suspicious. There's no way to be different these days. (inverse assessment)

28. The happiest people are upright and true

29. I admire people who have compassion, but I believe that this is something for the saints. In today's world you can't trust anyone. (inverse assessment)

30. No one is happy without having a good purpose in life.

31. Compassion is a pretty but hollow word because in fact people only think of themselves. (inverse assessment)

32. It is better to be betrayed, than to betray. He who betrays, first betrays himself.

33. A true friend does not hesitate to tell us what can embarrass us and to oppose our way of acting and thinking.

The Cronbach's alpha calculated for this subscale reached a value of 0.71 , which is considered satisfactory for the humanities. 
Table 4. Items of the subscale of predisposition to responsible actions and decisions (SPADR) and their correlations (Spearman Rank Order) with the average

Item

Correlation

34. To observe people's facial expressions is a way of trying to understand what is going on in them.

35. Getting on with each other in a group is very difficult. So as not to create conflicts, I prefer to let others take the decisions. (inverse assessment)

36. We have to face up to the challenges of everyday life with our head held high, confident that we have the strength to get through them.

37. When I am in a group, I try to take part in the decisions because I am also responsible for them.

38. We can only manage to talk coherently if we listen to each other closely.

39. I get upset when people insist on discussing a relationship. I do not see much sense in it. (inverse assessment)

40. We speak more appropriately when we pay attention to what the other needs.

41. I do not waste my time listening to someone speaking about something that is of no interest to me; I try to find a way to change the subject. (inverse assessment)

42. To solve a problem that affects some or several people, it is not good initially to be sure that we know what the most appropriate solution is.

43. In professional life, it is important to be accessible so that others can count on us to do whatever it takes.

44. I always worry about what I say because I know that peace in relationships depends on this.

45. I'm responsible for my actions and reactions in each relationship.

46. In group work, I try to keep my distance because there are always those who try to lean on others. (inverse assessment)

47. I try not to get involved in conflicts; let those who created them, solve them. (inverse assessment)

The Cronbach's Alpha calculated for this subscale reached a value of 0.63 , which is considered satisfactory for the humanities.

\section{Results}

With the items in each subscale validated by the Spearman correlation test, and each having its consistency measured by Cronbach's Alpha test, as per the data presented, it was therefore possible to consider each of the subscales as statistical indices for carrying out the $t$ Test to compare the means of two paired samples in order to ascertain whether or not the CCFHJA contributed to promoting human formation in the aforementioned aspects (knowledge of the emotions and cultivation of relationships, understanding of the virtues, predisposition to responsible decisions and actions) among the students who followed the course.

In Table 5, we present the parameters and results of this test for the three indexes (SRICE, SCCV, SPADR). 
Table 5. T Test for difference or equality of averages between the moments prior to and post applying the CCFHJA

\begin{tabular}{ccccccc}
\hline & \multicolumn{2}{c}{ T Test for difference or equality of the averages } & \multicolumn{2}{c}{ 95\% Confidence Interval } \\
\hline Index & $\mathrm{T}$ & $\begin{array}{c}\text { Bicaudal Sig } \\
(\mathrm{p} \text {-value })\end{array}$ & $\begin{array}{c}\text { Diff. in } \\
\text { averages }\end{array}$ & $\begin{array}{c}\text { Standard error } \\
\text { of the } \\
\text { difference }\end{array}$ & Smallest & Largest \\
\hline SRICE & -2.276 & 0.023 & -0.13428 & 0.05899 & -0.25025 & -0.01831 \\
SCCV & -4.065 & 0.000 & -0.20046 & 0.04931 & -0.29741 & -0.10351 \\
SPADR & -2.742 & 0.006 & -0.11445 & 0.04174 & -0.19650 & -0.03239 \\
\hline
\end{tabular}

The results shed light on statistical evidence of improvement between the pre- and post-situation of the students as to the indices of Interpersonal Relationship and Knowledge of the Emotions (SRICE), Understanding and Cultivation of the Virtues (SCCV) and Predisposition to Responsible Actions and Decisions (SPADR), which shows the possibility of there having been an increase in the degree of personal appropriation of the concepts investigated, which equally corroborates the understanding of the possibility that such a formation process can come to be implemented in regular education.

\section{Discussion and Final Remarks}

Since one of the limitations of the results shown in section 5 lies in the fact that we have not applied the same scale in a control group, bearing in mind that one of the authors was the only woman teacher to teach the discipline of interpersonal relations on the technological courses mentioned in the period 2009.22010 .1 , we complement our research with qualitative data analyzing written accounts of 135 individuals about their experience of translating the theoretical concepts to their everyday relationships. Among the main conclusions observed in the students' written accounts, we emphasize:

- Understanding the influence of emotions on thoughts can lead to an understanding about its scope, thus possibly favoring self-control; consequently, this state of awareness favors the reduction of relational wear and tear, i.e., can avoid negative development in the behavioral environment;

- The theoretical foundation of empathy, feedback and self-monitoring offers the mind resources to exercise more refined self-observation, and thus may lead to greater awareness in one's way of acting;

- The expansion of knowledge about the innermost areas of being tends to promote students' understanding of intrapersonal dynamics, relational creativity to overcome obstacles and divergences guided by the free will cultivation of virtues.

As in the scope of this article we do not have space to present qualitative research data in greater detail, we transcribe below, for purposes of exemplifying such conclusions, one of the testimonials from our students:

"[ ... [ It is natural that people undergo personality changes throughout their lives but the change that I've undergone has been conscious and, more importantly, voluntary. I realized that my lack of control over my feelings hindered my assessment and I later regretted my actions. On dealing with jealousy, my competitiveness, my pride and authoritarianism, I was able to give value to and practice feelings that were better for me and those around me, such as empathy and detachment. I know I'm very inexperienced and still have much to learn, but my willingness to improve will make me more socially skillful and more satisfied with myself. By learning to cope with feelings I do not mean to say I shall repressing them, but rather accept them. It is an aspect of maturing that many people fail to reach and which still needs a lot of clarification, such as how is one to judge an emotionally weakened person? Therefore there is a need to stimulate self-awareness in school formation so that adults do not turn out to be fragile and confused". (Student of Graphic Design)

As we stated throughout this article, the idea of human development is founded on the understanding that human beings must develop in order to hone everything that constitutes their being. Such development, however, is not established as a result of the simple maturation of one's somatic-psychological organization, but as a process that is intentionally structured to that end, throughout which the particular being will progressively become committed to the clarification which one obtains on the phenomena that inhabit one's interiority, one's relationship with those around one and the sense of how all these aspects are configured in one's life. This 
formative process extends or may extend throughout the life cycle of an individual, and may also be part of the more specific process we call education, which is characterized by structures and purposes delineated by social institutions that legitimize a certain direction of the formation process.

In accordance with the foregoing, therefore, to educate according to the sense of human formation includes but is not limited to the intentionality of humans appropriating to themselves various languages and from the logical-symbolical world (various languages, math, science, etc.) but also becoming capable of knowing and directing wisely the internal forces that inhabit them, such as the instincts, emotions and feelings, as well as of understanding and taking ownership of appropriate ways to establish relationships with other people in a way that becomes constructive and fulfilling for themselves.

When presented with themes and content that require reflection on what should guide human life, subjects are indirectly invited to contemplate for themselves the sphere of values and to understand why and how they point to what is valuable, what is worth doing (López-Quintás, 2004). However, just as no human being can on their own learn to read, to write, to use mathematical and scientific principles, so no human being can learn by $\mathrm{him} /$ herself, without the help of others, the other principles that shape the nature of their inner, relational and existential being. What is needed for this is an educational process in which such formation is its scope; understood in this way, education is part of the process of human formation (Policarpo Jr., 2011; Policarpo Jr. \& Röhr, 2012). It is in the wake of this understanding that the CCFHJA was formulated.

This research set out to investigate, in an exploratory way, the possibility of implementing a process of human formation of youths and adults in a regular teaching situation, more specifically those on higher technological courses in Brazil, which included other aspects besides cognitive formation such as knowledge of the emotions, the principles of relationships, of virtues and of responsible decisions and actions. Although, in the Brazilian educational field, education has not yet be designed to have such coverage, we ascertained the possibility of offering such training in regular schools, and of how this might become very successful, by expanding the sense of forming human beings so as to cover and link lessons they learn of cognitive, contemplative, relational, axiological and existential orders. We believe that further research and initiatives in this spirit may come to establish in Brazilian education the legitimacy of the idea of human formation as something that is intrinsic to it, as already happens in other parts of the world (UNESCO-APNIEVE, 1998, 2002, 2005).

Despite its relevance, we also recognize the limits of this research. We did not have the opportunity to compare the quantitative results achieved in the intervention with those that would originate from a control group. Moreover, the CCFHJA was taught by only one person and only one institution. It is, therefore, not legitimate to extrapolate the results to other situations without further research being done, and without future educators who will teach using it being trained to understand and take ownership of its content and meaning. It should also be noted that, due to the very character of intervention, our sample was not random, which also requires that we should conduct further research in order to determine whether or not to extend the conclusions reached here. Apart from these aspects, we recognize the need to refine our assessment tool in order to make it more concise and consistent. However, in spite of such limitations, we believe that the results achieved - also supported by qualitative data which were not analyzed in this article-are significant in contributing to the reflection on the need to expand the sense of formation of human beings beyond cognitive formation which today is the exclusive and hegemonic form in the field of Brazilian education.

\section{References}

Biaggio, A. M. B. (2002). Lawrence Kohlberg-ética e educação moral. São Paulo, SP: Moderna.

Dalai Lama XIV, B. (2012). Beyond Religion: ethics for a whole world. Boston, MA: Mariner Books; New York, NY: Houghton Mifflin Harcourt.

Delors, J., Al Mufti, I. A., Amagi, I., Carneiro, R., Chung, F., Bronislaw, G., . . Nanzhao, Z. (2003). Educação: um tesouro a descobrir-Relatório para a UNESCO da Comissão Internacional sobre Educação para o século XXI. Brasília, DF: MEC: UNESCO.

Elias, M. J., Zins, J. E., Weissberg, R. P., Frey, K. S., Greenberg, M. T., Haynes, N., . . Shriver, T. P. (1997). Promoting social and emotional learning: Guidelines for educators. Alexandria, VA (USA): Association for Supervision and Curriculum Development.

Erikson, E. H. (1994). The Life Cycle Completed-A review. New York: Norton \& Company.

Ferreira, A. L. (2012). Espiritualidade e educação: um diálogo sobre quão reto é o caminho da formação humana. In F. Röhr (Ed.), Diálogos em Educação e Espiritualidade (2nd ed., pp. 109-159). Recife, PE: Editora Universitária UFPE. 
Gardner, H. (1999). O Verdadeiro, o Belo e o Bom-os princípios básicos para uma nova educação. Rio de Janeiro, RJ: Objetiva.

Gardner, H. (2000). Inteligências múltiplas, a teoria na prática. Porto Alegre, RS: Artmed.

Gardner, H. (2007). Cinco Mentes para o Futuro. Porto Alegre, RS: Artmed.

Goleman, D. (2003). Como Lidar com Emoções Destrutivas-para viver em paz com você e os outros: diálogos com a contribuição do Dalai Lama. Rio de Janeiro, RJ: Campus.

Greenberg, M. T., \& Kusché, C. (2002). Promoting Alternative Thinking Strategies (PATHS). In D. S. Elliot (Ed.), Blueprints for Violence Prevention (Vol. 10). Boulder, CO: Institute of Behavioral Science, Regents of the University of Colorado.

Greenberg, M. T., \& Policarpo Junior, J.. (2008). Formação Humana e Desenvolvimento Emocional na Educação-o Currículo PATHS. Proceedings of the IV Colóquio Franco-Brasileiro de Filosofia da Educação (CD-ROM). Rio de Janeiro: Autêntica.

Jung, C. G. (2007). O Eu e o Inconsciente (20th ed.). Rio de Janeiro, RJ: Vozes.

Kabat-Zinn, J. (2005). Coming to Our Senses: Healing Ourselves and the World Through Mindfulness. Hyperion, USA.

Kornfield, J. (2002). Um Caminho com o Coração. São Paulo, SP: Cultrix.

Kusché, C. A., \& Greenberg, M. T. (1994). The PATHS Curriculum-Promoting Alternative Thinking Strategies. South Deerfield, MA: Channing L. Bete Co.

Kusché, C. A., \& Greenberg, M. T. (2012). Educação Emocional e Relacional para Crianças: pensamento, afetividade e trabalho com habilidades sociais (PATHS). Recife, PE: Instituto de Formação Humana.

López-Quintás, A.. (2004). Inteligência Criativa-descoberta pessoal de valores. São Paulo, SP: Paulinas.

Moroco, J., \& Garcia-Marques, T. (2006). Qual a fiabilidade do alfa de Cronbach? Questões antigas e soluções modernas? Laboratório de Psicologia. Lisboa, 4, 65-90.

Policarpo Jr., J. (2011). Cultura: sentidos da formação humana para o indivíduo e para a sociedade. In J. Policarpo Junior (Ed.), O Pensar, o Sentir, o Agir: sentidos da formação humana (E-book). Recife, PE: Instituto de Formação Humana. ISBN: 9781301869428.

Policarpo Jr., J. (2012). Um Caminho para uma vida integral e preciosa-reflexões sobre espiritualidade e educação. In F. Röhr (Ed.), Diálogos em Educação e Espiritualidade (2nd ed., pp. 81-107). Recife, PE: Editora Universitária UFPE.

Policarpo Jr., J., \& Röhr, F. (2012). Conceptual Grounding of Education as Human Formation-a dialogue between aspects of the field of Education itself and the Buddhist tradition. Education, 2(5), 195-208. http://dx.doi.org/10.5923/j.edu.20120205.13

Policarpo Jr, J., \& Rodrigues, M. L. F. de M. (2010). Princípios orientadores da formação humana: dimensão

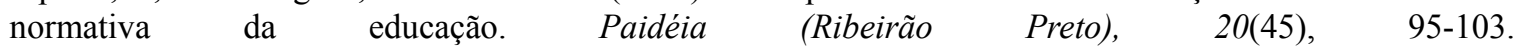
http://dx.doi.org/10.1590/S0103-863X2010000100012

Preece, R. (2006). The Wisdom of Imperfection: The challenge of individuation in Buddhist life. New York, NY: Snow Lion Publications.

Rodrigues, N. (2001). Educação: da Formação Humana à Construção do Sujeito Ético. Educ. Soc., 22(76), 232-257. http://dx.doi.org/10.1590/S0101-73302001000300013

Röhr, F. (2012). Espiritualidade e Educação. In F. Röhr (Ed.), Diálogos em educação e espiritualidade (pp. 13-52). Recife, PE: Ed. Universitária da UFPE.

Röhr, F. (2013). Educação e Espiritualidade-contribuições para uma compreensão multidimensional da realidade, do homem e da educação. Campinas, SP: Mercado das Letras.

UNESCO. (1972). Learning to be: The world of education today and tomorrow. Paris: UNESCO.

UNESCO-APNIEVE. (2002). Learning to be: A holistic and integrated approach to values education for human development: Core values and the valuing process for developing innovative practices for values education toward international understanding and a culture of peace. Bangkok: UNESCO Asia and Pacific Regional Bureau for Education.

UNESCO-APNIEVE. (2005). Learning to do: Values for learning and working together in a globalized world: 
An integrated approach to incorporating values education to technical and vocational education and training. Manila: APNIEVE.

United Nations Educational Scientific and Cultural Organization [UNESCO]-Asia Pacific Network for International Education and Values Education [APNIEVE]. (1998). Learning to live together in peace and harmony: Values education for peace, human rights, democracy and sustainable development of the Asia-Pacific region. Bangkok: UNESCO Principal Regional Office for Asia and the Pacific.

Zins, J. E., Weissberg, R. P., Wang, M. C., \& Walberg, H. J. (2004). Building Academic Success on Social and Emotional Learning: What does the research say? New York, NY: Teachers College Press.

\section{Copyrights}

Copyright for this article is retained by the author(s), with first publication rights granted to the journal.

This is an open-access article distributed under the terms and conditions of the Creative Commons Attribution license (http://creativecommons.org/licenses/by/3.0/). 